\title{
SENGKETA LINGKUNGAN HIDUP DALAM PERSPEKTIF HUKUM PERDATA LINGKUNGAN
}

Oleh :

\author{
Indah Sari, SH, M.Si \\ Dosen Tetap Fakultas Hukum Universitas Dirgantara Marsekal Suryadarma (Unsurya) dan \\ aktif di LKBH Fakultas Hukum Unsurya serta anggota Asosiasi Dosen Seluruh Indonesia (ADI) \\ Email : (indah.alrif.@gmail.com)
}

\begin{abstract}
Abstrak:
The growth of development and demands in people's life have brought us problem of environmental disputes. While there are disputes or quarrels between individuals, corporations, and state or government; the scoop of the disputes include private law, public law, administrative law, and international law. This writing is focused on environmental disputes based on private law, and also on the mechanism of dispute solutions -both through litigational or non-litigational mechanism. In litigational mechanism, people could submit a lawsuit for an act against law comitted by others based on article $1365 \mathrm{KUH}$ Perdata. In non-litigational mechanism, they need to find alternative dispute solution through processes of negotiation, mediation, consiliation, even arbitrage. Both mechanism, basically, try to make up for damage by compensation and also to recover environmental detriment for a better condition.
\end{abstract}

Semakin maraknya pembangunan dan juga besarnya tuntutan hidup masyarakat banyak menimbulkan permaslahan sengketa lingkungan hidup. Sengketa tersebut bisa terjadi antara individu dengan individu, individu dan badan hukum, badan hukum dan badan hukum, individu dan negara atau atau badan hukum dan negara. Sengketa lingkungan ini bermacam-macam ada sengketa lingkungan keperdataan, kepidanaan, administratif serta internasional. Pada tulisan ini penulis tertarik mengkaji mengenai apa yang dimaksud dengan sengketa lingkungan keperdataan dan bagaimana mekanisme penyelesaian sengeketa lingkungan keperdataan baik di dalam pengadilan ataupun di luar pengadilan. Dalam mekanisme pengadilan para pihak yang dirugikan akan melakukan gugatan ke pengadilan karena adanya perbuatan melawan hukum yang dilakukan oleh pihak lawan berdasarkan Pasal $1365 \mathrm{KUH}$ Perdata. Sedangkan mekanisme di luar pengadilan tentu akan mengikuti alur Altenatif Penyelesaian Sengketa yang dimulai dari negosiasi, mediasi, konsiliasi dan bahkan arbitase. Pada dasarnya harapan adanya penyelesaian sengketa lingkungan keperdataan ini adalah adanya tuntutan ganti rugi dan juga pemulihan lingkungan hidup pada keadaan semula dan bahkan lebih baik lagi.

\section{Pendahuluan}

Belakangan ini makin banyak kasus lingkungan yang bermunculan di tengah masyarakat, seiring dengan pesatnya dinamika aktivitas yang terdapat di masyarakat seperti di bidang industri, bisnis agrikultur (pertanian, perkebunan dan perikanan), agroforestry (bisnis komoditi kehutanan), property, konstruksi dan sebagainya. Kasuskasus lingkungan, tidak hanya terjadi 
antara pelaku usaha dengan pihak masyarakat, tetapi juga antara sesama pelaku usaha dalam hal interaksi usaha yang berekses lingkungan dan sumberdaya, antara pelaku usaha dengan pemerintah / pengelola kebijakan, dan antara masyarakat dengan pemerintah pula. Bahkan antar sesama masyarakat sendiri bisa terjadi sengketa menyangkut lingkungan, misalnya perebutan atau penguasaan badan-badan air di desa, pembakaran sampah menimbulkan tetangga "ribut-ribut". ${ }^{1}$

Semua ini merupakan aspek dinamika sosio-environmental, yang mekanisme penyelesaiannya masuk kepada institusi-institusi penyelesaian sengketa. Ada pilihan yang diambil oleh mereka yang terlibat dalam sengketa, yakni melalui pengadilan yang sifatnya alternatif, atau lazim disebut penyelesaian sengketa alternatif. Dikecualikan dari pilihan demikian, ialah jika menyangkut halhal kriminal (environmental crime), sengketa demikian harus tetap melalui pengadilan. $^{2}$

Mekanisme penyelesaian sengketa lingkungan terutama di pengadilan, mengalami perkembangan yang cukup pesat belakangan ini. Perkembangan demikian dapat dilihat dengan bergesernya mekanisme hukum acara perdata ke arah yang lebih luwes, dan mulai meninggalkan dimensi-dimensi hukum acara perdata yang bersifat konvensional selama ini, yang mendasarkan kepada sumber-sumber hukum acara yang ada (terutama HIR) misalnya dalam sengketa kerugian yang bersifat masal (mass victim), dapat dilakukan dengan gugatan perwakilan (class action), pihak lain dapat melakukan gugatan atas nama kepentingan meskipun sebenarnya tidak menjadi korban (legal standing), dan lainnya. Hal-hal demikian, merupakan kebijakankebijakan hukum yang meluaskan prinsip demokrasi di tengah masyarakat, khususnya dalam rangka menghubungkan semua lapisan masyarakat untuk mendukung hakhak dan kepentingannya melalui saluran-saluran institusi yang terbuka lebar (acces to justice). ${ }^{3}$

Adapun tujuan penulisan tulisan ini adalah:

1. Untuk mengkaji dan menganalisis lebih dalam apa sebenarnya sengketa lingkungan hidup tersebut, apa-apa saja bentuknya serta mengapa sengketa lingkungan hidup tersebut bisa terjadi dan efek apa yang di timbulkan dari sengketa lingkungan hidup tersebut. Dalam hal ini penulis fokus pada sengketa perdata lingkungan.

2. Untuk mendalami kajian tentang mekanisme penyelesaian sengketa lingkungan hidup dari sudut keperdataan. Terutama kajian mengenai mekanisme penyelesaian sengketa lingkungan dalam mekanisme peradilan (litigasi) maupun di luar sistem peradilan (non litigasi)

${ }^{1}$ N.H.T. Siahaan, Hukum Lingkungan, Pancuran

Alam, Jakarta, 2009, hal.259

${ }^{3}$ Ibid, hal. 260 


\section{Permasalahan}

Adapun permasalahan yang penulis angkat dalam tulisan ini adalah:

a. Apa yang dimaksud dengan sengketa lingkungan hidup?

b. Bagaimanakah bentuk dan mekanisme penyelesaian sengketa lingkungan hidup dalam perspektif hukum perdata lingkungan?

\section{Pembahasan}

\section{A. Sengketa Lingkungan Hidup}

Sengketa lingkungan hidup dapat dirumuskan dalam arti luas dan arti sempit. Dalam pengertian luas sengketa lingkungan hidup adalah perselisihan kepentingan antara dua pihak atau lebih yang timbul sehubungan dengan pemanfaatan sumber daya alam. Pemanfaatan sumber daya alam di samping memberikan manfaat pada sekelompok orang, juga dapat menimbulkan kerugian kepada kelompok lain, atau setidaknya meletakkan risiko kerugian kepada kelompok lain. Sering kali manfaat dari suatu kegiatan pemanfaat sumber daya alam dilihat secara makro, sementara risiko atau dampak negatif dari kegiatan itu dirasakan oleh sekelompok kecil orang. ${ }^{4}$

Sengketa lingkungan hidup (environmental disputes) sebenarnya tidak terbatas pada sengketasengketa yang timbul karena peristiwa pencemaran atau perusakan lingkungan hidup, tetapi

${ }^{4}$ Takdir Rahmadi, Hukum Lingkungan di Indonesia, Rajawali Pers, Jakarta, 2015, hal. 270. juga meliputi sengketa-sengketa yang terjadi karena adanya rencana-rencana kebijakan pemerintah dalam bidang pemanfaatan dan peruntukan lahan, pemanfaatan hasil hutan, kegiatan penebangan, rencana pembangunan pembangkit tenaga listrik, rencana pembangunan waduk, rencana pembangunan saluran udara tegangan tinggi. Dengan demikian sengketa lingkungan mencakup konteks yang relatif luas. ${ }^{5}$

Akan tetapi, UUPLH-1997 dan UUPPLH-2009 menganut perumusan sengketa lingkungan dalam arti sempit. ${ }^{6}$ Sengketa lingkungan hidup dalam UUPPLH-2009 dirumuskan dalam Pasal 1 butir 25 sebagai "perselisihan antara dua pihak atau lebih yang timbul dari kegiatan berpotensi dan /atau telah berdampak pada lingkungan hidup". ${ }^{7}$ Jadi fokusnya masih pada kegiatan, belum mencakup kebijakan atau program pemerintah yang berkaitan dengan masalah-masalah lingkungan hidup. Dalam UUPLH-1997 pengertian sengketa lingkungan dirumuskan dalam Pasal 1 butir 19 yaitu "perselisihan antara dua pihak atau lebih yang ditimbulkan oleh adanya atau diduga adanya

\footnotetext{
${ }_{6}^{5}$ Ibid, hal. 270-271-

${ }^{6}$ Lihat lebih lanjut Undang-Undang Lingkungn Hidup Nomor 23 Tahun 1997 dan Undang-Undang Perlindungan dan Pengelolaan Lingkungan Hidup Nomor 32 Tahun 2009.

${ }^{7}$ Lihat lebih lanjut Pasal 1 ayat 25 Undang-Undang Perlindungan dan Pengelolaan Lingkungan Hidup (UUPPLH) Nomor 32 Tahun 2009.
} 
pencemaran atau perusakan lingkungan hidup". 8

Kegiatan - kegiatan ekonomi seperti pendirian sebuah pabrik, penetapan lokasi pembuangan limbah, pembangunan waduk, pengambilan bahan tambang dan hasil hutan yang dapat merugikan kepentiangan suatu kelompok dalam masyarakat sehingga dapat menimbulkan sengketa dapat digolongkan ke dalam sengketa lingkungan. Ancaman terhadap hak dan kepentingan sah dari suatu kelompok dalam masyarakat juga berarti dapat menganggu lingkungan sosial masyarakat yang bersangkutan. ${ }^{9}$

Sengketa lingkungan berkisar kepada kepentingan-kepentingan atau kerugian - kerugian yang bersifat otonom, misalnya hilang atau terancamnya mata pencarian dan pemerosotan kualitas atau nilai ekonomi dari hak-hak kebendaan, dan juga berkaitan dengan kepentingan-kepentingan non ekonomi sifatnya. Misalnya terganggunya kesehatan, kegiatan rekreasional, keindahan dan kebersihan lingkungan. Diihat dari pihak yang terlibat, sengketasengketa lingkungan tidak selalu berupa pertikaian antara anggotaanggota masyarakat di satu pihak dengan pengusaha atau industri di lain pihak, tetapi juga pertikaian antara anggota-anggota masyarakat di satu pihak dengan pengusaha dan aparat pemerintah

${ }^{8}$ Lihat lebih lanjut Pasal 1 butir 19 Undang-Undang Pengelolaan Lingkungan Hidup (UUPLH) Nomor 23 Tahun 1997.

${ }^{9}$ Takdir Rahmadi, Op.Cit, 2015, hal. 271. di lain pihak. Aparat pemerintah kadang-kadang terlibat dalam sengketa dalam kedudukan sebagai tergugat karena perannya sebagai pihak yang memberikan izin atas kegiatan yang menimbulkan dampak negatif. Jenis sengketa lingkungan hidup yang pertama dikatakan bercorak perdata murni, sedangkan jenis yang kedua bercorak administratif. ${ }^{10}$ Pembahasan selanjutnya penulis akan mengkaji lebih dalam lagi sengketa lingkungan dalam perspektif hukum perdata atau bercorak keperdataan.

B. Sengketa Lingkungan Hidup dalam Perspektif Hukum Perdata Lingkungan

\section{Pengertian Hukum Lingkungan Keperdataan}

Hukum lingkungan keperdataan (privaatrechtelijk milieurecht) merupakan salah satu dari berbagai aspek hukum lingkungan lainnya. Sebagaimana yang dikatakan Drupsteen, bahwa hukum lingkungan meliputi pula aspek hukum administrasi, pidana, pajak, bahkan hukum internasional yang dalam perkembangannya telah menjadi bidang hukum yang berdiri sendiri. ${ }^{11}$

Dari segi substansinya, secara umum hukum lingkungan keperdataan menurut Munadjad Danusaputro mengandung

${ }^{10} \mathrm{Ibid}$, hal. 271-272

${ }^{11}$ Muhammad Akib, Hukum Lingkungan Perspektif Global dan Nasional, Rajawali Pers, Jakarta, 2014, hal. 179 dan lihat juga Drupsteen, Nederlands Milieurecht in Kort Bestek, 2e herziene druk, (Zwolle: W.E.J. Tjeeenk Willink, 1978). 
ketentuan-ketentuan yang mengatur tatanan masyarakat orang-seorang berikut badanbadan hukum perdata dan hubungan yang melandasi orangseorang berikut badan-badan hukum perdata satu sama lain, begitu pula yang melandasi hubungan hukum orang-seorang berikut badan-badan hukum perdata berhadapan dengan badan-badan negara, manakala badan-badan negara tersebut bertindak sebagai badan hukum perdata dalam menyelenggarakan hak dan kewajibannya. ${ }^{12}$ Pendapat ini masih bersifat umum, karena hanya menekankan pada pengaturan tatanan hubungan keperdataan pada umumnya dan belum difokuskan pada hubungan keperdataan dalam bidang lingkungan hidup. Hubungan keperdataan dalam bidang lingkungan akan terkait dengan pemenuhan hak dan kewajiban antar individu atau kelompok mengenai lingkungan hidup yang baik dan sehat. Jika hak salah satu pihak dirugikan, maka ia dapat meminta segera dihentikannya perbuatan yang menimbulkan kerugian itu dan sekaligus menuntut ganti kerugian serta pemulihan hak-hak yang dirugikan. ${ }^{13}$

Pendapat lain yang lebih tegas mengenai pengertian hukum lingkungan keperdataan dikemukan oleh Siti Sundari Rangkuti, bahwa hukum

12 Ibid, hal. 179 , di kutip dari Munajat

Danusaputro, Hukum Lingkungan, Buku I: Umum,

Cet, Kedua, (Bandung: Bina Cipta, 1985),hal.110.

${ }^{13} \mathrm{Ibid}$, hal 180. lingkungan keperdataan terutama mengatur perlindungan hukum bagi korban pencemaran dan/atau perusakan lingkungan akibat perbuatan pencemar yang menimbulkan kerugian bagi korban dan menyebabkan penderita berhak mengajukan gugatan ganti kerugian terhadap pencemar. ${ }^{14}$

Dari pendapat diatas, jelaslah bahwa hukum lingkungan keperdataan secara substansial memuat ketentuan yang berkaitan dengan pemenuhan hak-hak keperdataan seseorang. Kelompok orang dan badan hukum perdata dalam kaitannya dengan lingkungan hidup yang baik dan sehat. Jika hak-hak keperdataan ini dirugikan oleh salah satu pihak, misalnya karena terjadi pencemaran atau perusakan lingkungan, maka dalam upaya perlindungan hukumnya digunakan sarana hukum lingkungan keperdataan. Perlindungan lingkungan bagi korban pencemaran dan/atau kerusakan lingkungan diberikan dengan cara memberikan hak kepada penggugat untuk mengajukan gugatan ganti kerugian atau tindakan pemulihan lingkungan terhadap pencemar. ${ }^{15}$

\section{Strict Liability}

Perkembangan mengenai kepentingan korban atas kerugiankerugian yang diderita dari berbagai aktifitas yang berbahaya

${ }^{14}$ Ibid, hal.180 dan baca juga Siti Sundari Rangkuti, Hukum Lingkungan dan kebijaksanaan Lingkungan Nasional, Universitas Airlangga Pers, Surabaya, 2000, hal. 261.

${ }^{15}$ Ibid, hal. 180. 
tetapi sulit membuktikan kesalahan dari si pelaku, melahirkan sistem pertanggungjawaban khusus. Sistem demikian disebut dengan Strict Liability dikenal seiring dengan begitu rumitnya (complicated) mengenai aspek pertanggungjawaban perdata di bidang lingkungan. Beberapa faktor kesulitan mengidentifikasi luasan kerusakan/pencemaran lingkungan yang menjadi objek tanggungjawab terkait kepada faktor-faktor: ${ }^{16}$

Pertama, menelusuri aspek kausalitas dari kerusakan / pencemaran lingkungan tidaklah mudah karena media - media penyebab pencemaran/perusakan (substances) bisa sangat khusus dan toksis.

Kedua, sifat kerusakan tergantung pada media lingkungan yang tercemar atau rusak, jadi ada karakter lingkungan yang spesifik dan tidak bersifat mendasar (general).

Ketiga, sifat proses bekerjanya media - media penyebab pencemaran yang menimbulkan akibat (effect). Sifat dari mediamedia penyebab kerugian-kerugian lingkungan ada yang menimbulkan akibat seketika (direct effect). Akibat seketika inipun perlu pula dibedakan; a. bersifat direct lethal effect, yakni akibat pencemaran berupa kematian kepada organisma atau manusia dengan tempo yang singkat setelah peristiwa/ kejadian; b. Bersifat sub-lethal effect, yakni suatu akibat tetapi tidak dengan

${ }^{16}$ N.H.T. Siahaan, Op.Cit, 2009, hal. 336-337. mematikan langsung. Bentuk lain dari akibat (effect) yang merugikan lingkungan, yakni suatu akibat tetapi tidak dengan mematikan langsung tetapi tidak jarang pula bersifat kemudian (long term effect), artinya baru diketahui setelah berselang lama, misalnya setelah setahun atau lebih; dan c. Long term effect, yakni akibat yang baru diketahui setelah berlangsungnya jangka waktu berselang lama.

Keempat, terkait pula kepada faktor-faktor perubahan ekologis (ecological effect) yang memerlukan bantuan teknis.

UUPLH-1997 menyadari halhal demikian dan merumuskan asas tanggung jawab strict liability kepada kegiatan tertentu. Kegiatan tertentu tersebut adalah dampak besar dan penting, penggunaan bahan berbahaya dan beracun (B3), dan yang menghasilkan limbah B3. Asas strict liability dapat dilihat Pasal 35 ayat (1) UUPLH 1997 yang selengkapannya sebagai berikut: ${ }^{17}$

"Penanggungjawab usaha dan/atau kegiatan yang usaha kegiatannya menimbulkan dampak besar dan penting terhadap lingkungan hidup, yang menggunakan bahan berbahya dan beracun, dan/atau menghasilkan limbah bahan berbahaya dan beracun, bertanggungjawab secara mutlak atas kerugiaan yang ditimbulkan, dengan kewajiban membayar gantirugi secara langsung dan seketika pada saat

\footnotetext{
${ }^{17}$ Baca Pasal 35 ayat (1) UUPLH- 1997 mengatur tentang Strict Liability.
} 
terjadinya pencemaran dan/atau kerusakan lingkungan hidup"

Sedangkan mengenai Strict Liablity (tanggung jawab mutlak ) dalam UUPPLH-2009 menurut Pasal 88 dinyatakan bahwa: ${ }^{18}$

"Setiap orang yang tindakannya, usahanya, dan/atau mengelola limbah B3, dan/atau yang menimbulkan ancaman serius terhadap lingkungan hidup bertanggungjawab mutlak atas kerugian yang terjadi tanpa perlu pembuktian unsur kesalahannya."

Akhirnya kita dapat menyimpulkan bahwa unsur-unsur dari Strict Liability meliputi:

1. Adanya suatu perbuatan atau kegiaatan

2. Menimbulkan dampak besar dan penting bagi lingkungan hidup

3. Menggunakan atau menghasilkan bahan/limbah berbahaya dan beracun

4. Tanggungjawab timbul secara mutlak

5. Tanggungjawab secara langsung dan seketika pada saat pencemaran/perusakan lingkungan.

\section{Ganti Rugi, Tindakan Tertentu,} dan Pembayaran Uang Paksa

Menurut Pasal 87 ayat (1) UUPPLH 2009, ada dua jenis ganti rugi yaitu: ${ }^{19}$
1. Ganti rugi kepada orang yang menderita kerugian akibat pencemaran dan/ atau kerusakan lingkungan.

2. ganti rugi kepada lingkungan hidup itu sendiri

Selain kewajiban membayar ganti rugi tersebut pencemar dan/atau perusak lingkungan dapat dikenakan tindakan hukum tertentu, misalnya perintah untuk:

a. memasang atau memperbaiki unit pengolahan limbah sehingga limbah sesuai dengan baku mutu lingkungan hidup yang ditentukan.

b. memulihkan fungsi lingkungan hidup; dan/atau

c. menghilangkan atau memusnahkan penyebab timbulnya pencemaran dan / atau perusakan lingkungan hidup

Dalam kaitannya dengan pembebanan untuk melakukan tindakan hukum tersebut, dalam Pasal 87 ayat (3) dan ayat (4) UUPPLH 2009 ditentukan bahwa pengadilan dapat menetapkan pembayaran uang paksa terhadap setiap hari keterlambatan atas pelaksanaan putusan pengadilan. Besarnya uang paksa diputuskan berdasarkan peraturan perundangundangan. Pembayaran uang paksa ini harus melalui pengadilan untuk menjamin agar putusannya dilaksanakan, sehingga berbeda dengan maksud uang paksa

${ }^{18}$ Lihat pasal 88 UUPPLH-2009

${ }^{19}$ Lihat pasal 87 ayat (1) UUPPLH-2009 
(dwangsom) sebagai sanksi hukum adimistrasi. ${ }^{20}$

Dalam UUPPLH-2009 tidak dinyatakan bagaimana bentuk, jenis dan besaranya ganti rugi yang dapat digugat. Untuk itu sebagai perbandingan menurut Yurisprudensi di Jepang bahwa tuntutan terhadap korban pencemaran tidak hanya terbatas pada biaya perawatan medik, melainkan meliputi rasa sakit dan penderitaan cacat. Bahkan menurut Yurisprudensi kasus Nigata dan Komamoto, ganti kerugiaan yang dituntut dapat berupa hilangnya kesempatan untuk menikah, hilangnya mata pencarian, dan terhadap keluarga yang ditinggalkan oleh penderita yang meninggal dunia dapat menuntut ganti kerugiaan berupa: bantuan kekurangan pada anak yang masih ditanggung suami/istri, orang tua dan anak yang belum dewasa, tunjangan anak, wanita hamil yang terganggu kandungannya dan sebagainya. Dalam kasus ini pada umumnya penggugat hanya menggugat hal yang berhubungan dengan derita dan emosional dan mental serta biaya pengacara.$^{21}$

\footnotetext{
${ }^{20}$ Baca Pasal 87 ayat (3) dan (4) UUPPLH-2009 mengenai besarnya pembayaran uang paksa dalam sengketa perdata lingkungan.

${ }^{21}$ Muhammad Akib. Op.Cit, 2014, hal 190 yang dikutip dari Siti Sundari Rangkuti, Hukum Lingkungan Keperdataan, Tanggung Gugat Pencemar dan Beban Pembuktian, Bahan Penataran, Penataran Nasional Hukum Lingkungan Eks Kerjasama Hukum Indonesai-Belanda, Surabaya, Fakultas Hukum Unair, 11-17 Januari 1994, hal. 295 dan Siti Sundari Rangkuti, Inovasi Hukum lingkungan: Dari Ius Constitutum ke Ius Constituendum, Pidato Pengukuhan, Peresmian Penerimaan Guru Besar pada Fakultas Hukum Universitas Airlangga, Surabaya, 11 Mei 1991, hal.14,
}

Kemungkinan dapat terjadi gugatan terhadap hilangnya mata pencarian (loss of income) karena cacat fisik (loss of ability to work). Disamping itu, bentuk ganti kerugiaan dapat pula menyangkut hilangnya kesempatan untuk menikah (the loss of oppurtunity for marriage). ${ }^{22}$

\section{Gugatan dalam Hukum Perdata Lingkungan Gugatan Perorangan}

Setiap peristiwa lingkungan hidup yang berupa pencemaran maupun perusakan pada umumnya warga masyarakat sekitarnya merasa dirugikan karena kehidupannya terganggu antara lain udara kotor, bau tidak sedap, air tidak dapat dimanfaatkan, banjir dan sebagainya. Warga masyarakat yang dirugikan mempunyai hak menggugat terhadap pihak yang menyebabkan terganggunya lingkungan hidup. ${ }^{23}$

Warga yang menggugat mempunyai hubungan langsung dengan peristiwanya karena mereka sebagai korban, dan tujuannya adalah untuk mendapatkan ganti kerugian. Selain itu, gugatan bertujuan agar pihak tergugat melakukan pemulihan lingkungan hidup yang rusak. Gugatan ke pengadilan dapat diajukan secara sendirisendiri. ${ }^{24}$

Hak gugat hanya dapat dipergunakan oleh subjek hukum

22 Ibid.

${ }^{23}$ Gatot Supramono, Penyelesaian Sengketa

Lingkungan Hidup Di Indonesia, Penerbit Rineka Cipta, Jakarta, 2013, hal. 69

24 Ibid, hal. 69 
apabila memiliki kepentingan hukum yang cukup (point d'intered, point d'action). Hal tersebut sesuai dengan Putusan Mahkamah Agung RI tanggal 7 Juli 1971 No. 294/X/Sip/1971 yang menyatakan bahwa gugatan harus diajukan oleh orang yang mempunyai hubungan hukum (Zahir,1999). ${ }^{25}$ Pengajuan gugatan perorangan ini sesuai dengan prinsip hukum perdata sebagai hukum pribadi, kerena masing-masing orang memiliki kemauan tidak sama. Dalam sengketa lingkungan hidup walaupun kepentingan masingmasing korban sama untuk meminta ganti kerugian akan tetapi besarnya kerugian yang berbedabeda. ${ }^{26}$

\section{Gugatan Kelompok (Class Action)}

Istilah class action (CA) atau yang disebut pula dengan actio popularis diartikan dalam bahasa Indonesia secara beragam disebut dengan gugatan perwakilan, gugatan kelompok atau ada juga yang menyebutnya gugatan yang berwakil. Terminologi ini pada awalnya merupakan terminologi hukum acara yang dipakai dalam sistem common law. Sistem Hukum Acara Perdata Indonesia yang didasarkan pada HIR (Herziene Indlands Reglement) atau RBg (Reglement Buitengewesten) pada dasarnya tidak mengenal mekanisme gugatan class action. Hanya kebanyakan negara-negara yang bersistem anglo-saxon yang mengenal lembaga tersebut. ${ }^{27}$

Dalam hukum lingkungan keperdataan tidak selalu terdapat sengketa lingkungan antar individu, tetapi juga atas nama kelompok masyarakat dengan kepentingan yang sama melalui gugatan kelompok (class action) atau yang di Amerika dikenal dengan "actio popularis". Gugatan perdata dalam perkara lingkungan tidak saja menyangkut hak milik atau kerugian, tetapi juga kepentingan lingkungan yang baik dan sehat bagi masyarakat. Peranan class action penting dalam kasus pencemaran yang menyangkut a mass of people, dipedesaan, yaitu rakyat biasa yang awam dalam ilmu. ${ }^{28}$

Mahkamah Agung (PERMA) RI No.1 Tahun 2002 tentang Acara Gugatan Perwakilan Kelompok. Dalam Pasal 1 huruf a Peraturan Mahkamah Agung ini ditentukan bahwa: ${ }^{29}$

"Gugatan Perwakilan kelompok adalah suatu tata cara pengajuan, dalam mana satu orang atau lebih yang mewakili kelompok mengajukan gugatan untuk diri atau diri-diri mereka sendiri dan sekaligus mewakili sekelompok orang yang jumlahnya banyak, yang memiliki kesamaan fakta atau dasar hukum antara wakil kelompok dan anggota kelompok yang dimaksud."

${ }^{25}$ Baca juga Putusan Mahkamah Agung RI tanggal

7 Juli 1971 No. 294/X/Sip/1971.

${ }^{26}$ Gatot Supramono, Op.Cit, 2013, hal. 69

${ }^{27}$ N.H.T. Siahaan, Op.Cit, 2009, hal. 270

${ }^{28}$ Muhammad Akib, Op.Cit, 2014, hal. 190-191.

${ }^{29}$ PERMA RI No.1 Tahun 2002 Tentang Acara

Gugatan Perwakilan Kelompok. 
Apakah dalam Undang-Undang Perlindungan dan Pengelolaan Lingkungan Hidup juga diatur gugatan class action? Gugatan class action tidak mendapat pengaturan dalam UULH-1982. Prosedur ini baru diatur melalui Pasal 37 ayat (1) UUPLH-1997, di mana dinyatakan bahwa :30

" Masyarakat berhak mengajukan gugatan perwakilan ke pengadilan dan/atau melaporkan ke penegak hukum mengenai masalah lingkungan hidup yang merugikan perikehidupan masyarakat"

\section{UUPLH-1997}

tidak menjelaskan apa yang dimaksud dengan gugatan perwakilan. Akan tetapi jika kita lihat mengenai penjelasan Pasal 37 ayat (1) diatas, dikatakan bahwa yang dimaksud hak mengajukan gugatan perwakilan adalah hak kelompok kecil masyarakat untuk bertindak mewakili masyarakat dalam jumlah besar yang dirugikan atas dasar kesamaaan permasalahan, fakta hukum, dan tuntutan yang ditimbulkan karena pencemaran dan/atau perusakan lingkungan hidup.

Jika mau diuraikan maka unsurunsur dari gugatan perwakilan menurut UUPLH-1997 adalah:

a. sekelompok kecil masyarakat

b. mewakili masyarakat korban

c. berdasarkan kesamaan masalah, fakta hukum dan tuntutan d. kerugian karena pencemaran atau perusakan lingkungan hidup.

Gugatan class action kemudian diatur kembali dalam Pasal 91 UUPPLH-2009 yang menentukan: ${ }^{31}$

(1) Masyarakat berhak mengajukan gugatan perwakilan kelompok untuk kepentingan dirinya sendiri dan/atau untuk kepentingan masyarakat apabila mengalami kerugian akibat pencemaran dan / atau kerusakan lingkungan hidup.

(2) Gugatan dapat diajukan apabila terdapat kesamaan fakta atau peristiwa, dasar hukum, serta jenis tuntutan diantara wakil kelompok dan anggota kelompoknya.

(3) Ketentuan mengenai hak gugat masyarakat dilaksanakan sesuai dengan peraturan perundangundangan.

Dari uraian diatas sudah jelas sengketa lingkungan hidup mengenal adanya gugatan perwakilan di Indonesia sudah diatur dalam UUPLH-1997 dan UUPPLH-2009. Sebenarnya gugatan perwakilan merupakan penyerapan dari konsep class action yang dikenal dalam sistem Anglo Saxon. Pengertian class action dalam Pasal 23 Hukum Acara Perdata Amerika Serikat (the US

${ }^{30}$ Lihat pasal 37 ayat (1) UUPLH-1997 mengatur tentang Gugatan Class Action

${ }^{31}$ Pasal 91 UUPPLH-2009 yang mengatur tentang prosedur gugatan kelompok dalam sengketa lingkungan hidup. 
Rules of Civil Prosedure) adalah: "one more members of a class to use or to be sued as representative parties on the behalf of all". Prasyarat untuk mengajukan gugatan class action adalah sebagai berikut: ${ }^{32}$

1) the class is so numerous that joinder of all members is impracticable

2) there are questions of law or fact common to the class

3) the claims or defenses of the representatives parties are typical of the claims or defenses of the class, and representatives parties will fairly and adequately protect the interests of the calss.

Belakangan ini sistem gugatan
class action cukup banyak
diterapkan dalam berbaga
gugatan yang menyangkut kepentingan dan kebijakan publik. Bahkan bukan saja dalam masalah lingkungan, tetapi juga dalam masalah masalah yang menyangkut kebijakan politik, penetapan harga, pemecatan buruh, periklanan, konsumen dan lain-lain. Pada intinya dalam mengajukan gugatan perwakilan kelompok (class action) apabila terdapat kesamaan fakta atau peristiwa, dasar hukum, serta jenis tuntutan di antara wakil kelompok dan anggota kelompoknya. Kesamaan dimaksud tidak lain adalah kerugian akibat pencemaran dan/atau kerusakan lingkungan hidup.

${ }^{32}$ Takdir Rahmadi, Op.Cit, 2015, hal.274

\section{Gugatan Legal Standing}

Gugatan terhadap perkara lingkungan tidak saja menyangkut hak milik atau kerugian, tetapi juga kepentingan lingkungan yang baik dan sehat bagi warga masyarakat. Dalam rangka untuk kepentingan lingkungan inilah diperlukan adanya kewenangan menggugat (ius standi/legal standing/standing to sue) dari organisasi lingkungan. Namun demikian penerapan legal standing organisasi lingkungan ini tidaklah mudah, karena ada doktrin hukum perdata tradisional yang menganut asas "tiada gugatan tanpa kepentingan hukum" (point d'interest, point d'action) yang hanya memungkinkan kewenangan menggugat atas dasar kepentingan dan hubungan hukum dengan tergugat serta menimbulkan kerugian. ${ }^{33}$

Pengakuan secara tegas mengenai legal standing organisasi lingkungan semula terdapat dalam Pasal 38 UUPLH-1997. Ketentuan ini diatur kembali dalam Pasal 92 UUPPLH-2009 yang menentukan: ${ }^{34}$

(1) Dalam rangka pelaksanaan tanggung jawab perlindungan dan pengelolaan lingkungan hidup, organisasi lingkungan hidup berhak mengajukan gugatan untuk kepentingan pelestarian fungsi lingkungan hidup.

\footnotetext{
${ }^{33}$ Muhammad Akib, Op.Cit, 2014, hal. 194 dikutip dari Siti Sundari Rangkuti, Inovasi Hukum Lingkungan: Dari Ius Constitutum ke Ius Constituendum, Pidato Pengukuhan, Peresmian Penerimaan Guru Besar pada Fakultas Hukum Universitas Airlangga Surabaya, 11 Mei 1991. hal. 18

${ }^{34}$ Baca Pasal 38 UUPLH-1997 dan Pasal 92 UUPPLH-2009.
} 
(2) Hak mengajukan gugatan terbatas pada tuntutan untuk melakukan tindakan tertentu tanpa adanya tuntutan ganti rugi, kecuali biaya atau pengeluaran riil.

(3) Organisasi lingkungan hidup dapat mengajukan gugatan apabila memenuhi persyaratan:

a. berbentuk badan hukum

b. menegaskan di dalam anggaran dasarnya bahwa organisasi tersebut didirikan untuk kepentingan pelestarian fungsi lingkungan hidup dan

c. telah melaksanakan kegiatan nyata sesuai dengan anggaran dasarnya paling lambat 2 (dua) tahun.

Melalui ketentuan Pasal 92 ayat (1) UUPPLH-2009 secara tegas diakui hak standing organisasi lingkungan untuk mengajukan gugatan untuk dan atas nama kepentingan lingkungan. Hak standing ini diberikan selaras dengan adanya pengakuan hak setiap orang, termasuk badan hukum atas lingkungan hidup yang baik dan sehat. ${ }^{35}$

Tidak semua hal dapat digugat oleh organisasi lingkungan. Pasal 92 ayat (2) UUPPLH-2009 membatasi bahwa yang dapat digugat terbatas pada tuntutan untuk hak melakukan tindakan tertentu tanpa adanya tunttutan ganti rugi, kecuali biaya atau pengeluaran riil. Meskipun tidak ada penjelasan apa yang dimaksud dengan biaya atau pengeluaran riil, tentu yang dimaksud adalah biaya yang nyata-nyata dapat dibuktikan telah dikeluarkan oleh organisasi lingkungan hidup. Dengan demikian yang menjadi fokus gugatan organisasi lingkungan bukanlah ganti rugi, tetapi tindakan tertentu untuk pelestarian fungsi lingkungan hidup, misalnya membuat atau memperbaiki unit pengolahan limbah, menebar kembali (restocking) bibit ikan, melakukan penanaman pohon di sekitar areal perusahaan, dan lain sebagainya yang sifatnya untuk memulihkan fungsi lingkungan hidup atau menghilangkan penyebab pencemaran dan/atau kerusakan lingkungan. ${ }^{36}$

Dengan demikian tidak semua oraganisasi lingkungan mempunyai hak untuk mengajukan gugatan. Seperti yang telah dijelaskan diatas dimana Pasal 92 ayat (3) UUPPLH-2009 bahwa organisasi yang dapat mengajukan gugatan adalah harus memenuhi tiga kriteria yaitu: pertama, berbentuk badan hukum, kedua, menegaskan di dalam anggaran dasarnya bahwa organisasi tersebut didrikan untuk kepentingan pelestarian lingkungan hidup dan yang ketiga, telah melaksanakan kegiatan nyata sesuai dengan anggaran dasarnya paling singkat 2 (dua) tahun. Jika salah satu persyaratan di atas tidak terpenuhi maka gugatan tidak dapat diterima. Hal ini dimaksudkan bahwa gugatan benar-benar diajukan oleh organisasi lingkungan yang kredibel serta mempunyai program

${ }^{35}$ Muhammad Akib, Op.Cit, 2014, hal.199.

${ }^{36} \mathrm{Ibid}$, hal.199-200 
nyata untuk pelestarian lingkungan hidup.

Selaras dengan ketentuan Pasal 92 UUPPLH-2009, kewenangan menggugat dari organisasi lingkungan yang bergerak di bidang kehutanan juga diakui dalam Pasal 73 UU No.41 Tahun 1999 tentang Kehutanan yang menentukan: ${ }^{37}$

(1) Dalam rangka pelaksanaan tanggung jawab pengelolaan hutan, organisasi bidang kehutanan berhak mengajukan gugatan perwakilan untuk kepentingan pelestarian fungsi hutan

(2) Organisasi bidang kehutanan yang berhak mengajukan gugatan sebagaimana dimaksud pada ayat (1) harus memenuhi persyaratan:

a. berbentuk badan hukum

b. organisasi tersebut dalam anggaran dasarnya dengan tegas menyebutkan tujuan didirikannya organisasi untuk kepentingan pelestarian fungsi hutan dan

c. tidak melaksanakan kegiatan sesuai dengan anggaran dasarnya.

\section{Gugatan Citizen Standing/Citizen Law Suit}

Citize Lawsuit sendiri lahir dari negara-negara yang menganut sistem hukum Common Law, dan dalam sejarahnya citizen lawsuit

${ }^{37}$ Baca Pasal 73 Undang-Undang Nomor 41 Tahun 1999 tentang Kehutanan. pertama kali diajukan terhadap permasalahan lingkungan hidup. Namum pada perkembangannya citizen lawsuit tidak lagi hanya diajukan dalam perkara lingkungan hidup, tetapi pada semua bidang dimana negara dianggap melakukan kelalaian dalam memenuhi hak warga negaranya (Mahkamah Agung, 2009:50) $^{38}$

Secara sederhana citizen lawsuit adalah mekanisme gugatan warga negara terhadap penyelenggara negara berkenaan kepentingan umum, bukan untuk kepentingan pribadi atau orang perorang. Unsur kepentingan umum ini membuatnya menjadi tidak sama dengan Gugatan Tata Usaha Negara walaupun kedua mekanisme ini sama-sama menggugat penyelenggara negara. Inti citizen lawsuit adalah menggugat tanggungjawab penyelenggara negara atas kelalaian memenuhi hak-hak warga negara. Kelalaian tersebut didalilkan sebagai perbuatan melawan hukum (onrechtmatigedaad). Atas kelalaian itu negara dihukum untuk memperbaikinya dengan cara mengeluarkan suatu kebijakan yang mengatur umum ( regeling) agar pelanggaran hak warga negara tersebut tidak terjadi lagi dikemudian hari (Darmi, 2011) ${ }^{39}$.

Citizen lawsuit yang merupakan mekanisme beracara di pengadilan, dimaksudkan untuk

\footnotetext{
${ }^{38}$ Gatot Supramono, Op.Cit, 2013, hal. 75.

${ }^{39}$ Ibid, hal,75-76 dikutip dari Darmi, Mari Mengenal Gugatan Warga Negara (Citizen Lawsuit), htpp;/www.acehinstitute.org, 24 Agustus 2011.
} 
melindungi warga masyarakat dari kemungkinan terjadinya kerugian akibat tindakan atau kebijakan atau karena tidak-berbuatan (omission) oleh pemerintah atau pengambil keputusan. ${ }^{40}$

Citizen lawsuit yang diajukan tidak ada hubungannya dengan ganti kerugian. Seorang warga negara menggugat bukan karena yang bersangkutan sebagai korban yang menderita kerugian dan gugatannya bukan untuk menuntut ganti kerugian. Gugatan ini tidak sama dengan class action, karena pada citizen lawsuit tidak mewakili orang lain, hanya mewakili diri sendiri sebagai warganegara.

Ada beberapa kasus citizen lawsuit yang cukup dikenal adalah sebagai berikut: ${ }^{41}$

\section{Di Amerika Serikat}

Gugatan seorang Warga Negara Amerika atas kelalaian Pemerintah dalam melakukan pelestarian terhadap spesies kelelawar langka di Amerika. Gugatan tersebut dikabulkan dan hasilnya adalah pemerintah Amerika mengeluarkan Act tentang Konservasi kelelawar langka tersebut.

\section{Di India}

Gugatan seorang warga negara India atas kelalaian Pemerintah India dalam melestarikan sungai Gangga yang merupakan sungai suci bagi umat Hindu. Hasilnya adalah larangan

${ }^{40}$ N.H.T. Siahaan, Op, Cit, 2009, hal.291.

${ }^{41}$ Gatot Supramono, Op.Cit, 2013, hal. 77-78. pemerintah India kepada pabrik-pabrik disekitar sungai Gangga melakukan pencemaran terhadap sungai

(http;/kanadianto.wordpress.com)

Menurut Darmi (2011) terdapat 4 (empat) karakteristik citizen lawsuit berdasarkan beberapa perkara yang pernah diputuskan oleh pengadilan Indonesia yang menggunakan mekanisme ini. Karakteristik ini disusun dengan memperhatikan batasan-batasan yang telah ada dalam mekanisme acara yang lain (perdata umum, TUN, dan MK), yaitu:

a. Penggugat adalah warga negara yang bertindak mengatasnamakan seluruh atau sebagian Warga Negara Indonesia.

b. Tergugat adalah penyelenggara negara, dari Presiden Republik Indonesia, Menteri dan terus sampai kepada pejabat negara di bidang yang dianggap telah melakukan kelalaian dalam memenuhi hak warga negaranya,

c. Perbuatan melawan hukum yang digugat adalah kelalaian penyelenggara negara dalam pemenuhan hak-hak warga negara. Dalam gugatan harus jelas diuraikan bentuk kelalaian negara sehingga hak warga negara menjadi tidak terpenuhi. Hak warga negara yang gagal dipenuhi oleh negara juga harus dijelaskan.

d. Surat gugatan mekanisme ini ditandai oleh beberapa karakteristik khas yaitu 
tuntutan (petitum) dalam gugatan ini harus berisi permohonan agar negara mengeluarkan suatu kebijakan yang mengatur umum (regeling) agar perbuatan melawan hukum berupa kelalaian negara dalam pemenuhan hak warganya tersebut dimasa yang akan datang tidak terjadi lagi.

Keempat karakteristik diatas harus tergambarkan di dalam gugatan jika seseorang mengatasnamakan dirinya untuk kepentingan seluruh warga Indonesia agar terjadi perbaikan dalam penyelenggaraan negara terhadap hak-hak warga negaranya. Sehingga barulah terpenuhinya unsur-unsur citizen lawsuit.

\section{D.Penyelesaian Sengketa dalam Hukum Perdata Lingkungan}

Sengketa lingkungan pada dasarnya adalah perselisihan yang timbul sebagai akibat adanya atau di duga adanya dampak lingkungan hidup. Dalam Pasal 1 angka 25 UUPPLH- 2009 ${ }^{42}$ dirumuskan sengketa lingkungan adalah perselisihan antara dua pihak atau lebih yang timbul dari kegiatan yang berpotensi dan/atau telah berdampak pada lingkungan hidup. Dengan demikian, yang menjadi subjek sengketa adalah pelaku dan korban dari dampak lingkungan, sedangkan objek sengketa adalah kegiatan yang berpotensi dan / atau telah

${ }^{42}$ Lihat Pasal 1 angka 25 Undang-Undang Nomor 32 Tahun 2009 tentang Perlindungan dan Pengelolaan Lingkungan Hidup (UUPPLH-2009) berdampak pada lingkungan hidup. Mekanisme penyelesaiannya menurut Pasal 84 ayat (1) UUPPLH-2009 ${ }^{43}$ dapat dilakukan melalui jalur pengadilan (litigasi) atau jalur di luar pengadilan (non litigasi) atau yang lebih dikenal dengan penyelesaian sengketa alternatif. Sebagaimana yang dirumuskan dalam Pasal 84 UUPPLH-200944:

1. Penyelesaian sengketa lingkungan hidup dapat ditempuh melalui pengadilan atau di luar pengadilan.

2. Pilihan penyelesaian sengketa lingkungan hidup dilakukan secara sukarela oleh para pihak yang bersengketa.

3. Gugatan melalui pengadilan hanya dapat ditempuh apabila upaya penyelesaian sengketa di luar pengadilan yang dipilih dinyatakan tidak berhasil oleh salah satu atau para pihak yang bersengketa.

Lebih lanjut mari kita melihat bagaimana pengaturan penyelesaian sengketa lingkungan dari sudut pandang keperdataan sebagaimana yang diatur dalam Undang-Undang Nomor 32 Tahun 2009 tentang Perlindungan dan Pengelolaan Lingkungan hidup:

${ }^{43}$ Baca Pasal 84 ayat (1) Undang-Undang Nomor 32 Tahun 2009 tentang Perlindungan dan Pengelolaan Lingkungan Hidup (UUPPLH-2009)

${ }^{44}$ Lihat lebih lanjut Pasal 84 ayat (1), (2), (3) UUPPLH-2009 
Penyelesaian Sengketa

Lingkungan Hidup di luar

Pengadilan ${ }^{45}$ :

Pasal 85:

(1). Penyelesaian sengketa lingkungan hidup di luar pengadilan dilakukan untuk mencapai kesepakatan mengenai:

a. Bentuk dan besarnya ganti rugi

b. Tindakan pemulihan akibat pencemaran dan / atau perusakan

c. Tindakan tertentu untuk menjamin tidak akan terulangnya pencemaran dan / atau perusakan dan/atau

d. Tindakan untuk mencegah timbulnya dampak negatif terhadap lingkungan hidup

(2) Penyelesaian sengketa di luar pengadilan tidak berlaku terhadap tindak pidana lingkungan hidup sebagaimana yang diatur dalam Undang-Undang ini.

(3) Dalam menyelesaikan sengketa lingkungan diluar pengadilan dapat digunakan jasa mediator dan / atau arbiter untuk membantu menyelesaikan sengketa lingkungan hidup.

\section{Pasal 86}

(1) Masyarakat dapat membentuk lembaga penyedia jasa penyelesaian sengketa lingkungan hidup yang bersifat bebas dan tidak berpihak.

(2) Pemerintah dan pemerintah daerah dapat memfasilitasi pembentukan lembaga penyedia jasa penyelesaian sengketa lingkungan hidup yang bersifat bebas dan tidak berpihak.

(3) Ketentuan lebih lanjut mengenai lembaga penyedia jasa penyelesaian sengketa lingkungan hidup diatur dengan Peraturan Pemerintah.

Penyelesaian Sengketa Lingkungan Hidup melalui Pengadilan: ${ }^{46}$

\section{Pasal 87}

(1) Setiap penanggung jawab usaha dan / atau kegiatan yang melakukan perbuatan melanggar hukum berupa pencemaran dan / atau perusakan lingkungan hidup yang menimbulkan kerugian pada orang lain atau lingkungan hidup wajib membayar ganti rugi dan/atau melakukan tindakan tertantu.

(2) Setiap orang yang melakukan pemindahtanganan, pengubahan sifat dan bentuk usaha, dan/atau kegiatan dari suatu badan usaha yang melanggar hukum tidak

\footnotetext{
${ }^{46}$ Penyelesaian sengketa lingkungan hidup dalam perspektif keperdataan melalui Pengadilan diatur pada Pasal 87, 88, dan 89, UUPPLH-2009.
}

${ }^{45}$ Bahwasannya Penyelesaian sengketa lingkungan hidup di luar pengadilan (non litigasi) diatur dalam Pasal 85 dan 86 UUPPLH -2009. 
melepaskan tanggung jawab hukum dan/atau kewajiban badan usaha tersebut.

(3) Pengadilan dapat menetapkan pembayaran uang paksa terhadap setiap hari keterlambatan atas pelaksanaan putusan badan usaha tersebut.

\section{Pasal 88}

Setiap orang yang tindakannya, usahanya, dan / atau kegiatannya menggunakan B3 (Bahan Berbahaya dan Beracun), menghasilkan dan / atau mengelola limbah B3, dan/atau yang menimbulkan ancaman serius terhadap lingkungan hidup bertanggungjawab mutlak atas kerugian yang terjadi tanpa perlu pembuktian unsur kesalahan.

\section{Pasal 89}

(1) Tenggat kadaluarsa untuk mengajukan gugatan ke pengadilan mengikuti tenggang waktu sebagaimana diatur dalam ketentuan Kitab Undang - Undang Hukum Perdata dan dihitung sejak diketahui adanya pencemaran dan / atau kerusakan lingkungan hidup.

(2) Ketentuan mengenai tenggat kadaluarsa tidak berlaku terhadap pencemaran dan / atau kerusakan lingkungan hidup yang di akibatkan oleh usaha dan / atau kegiatan mengelola B3 serta menghasilkan dan / atau mengelola limbah B3.

\section{Pilihan Penyelesaian Sengketa \\ Lingkungan Hidup di Luar Pengadilan}

Sebagaimana diuraikan diatas bahwa penyelesaian sengketa lingkungan dalam perspektif keperdataan bisa dilakukan di dalam dan di luar pengadilan. Penyelesaian sengketa di luar pengadilan yang dalam kepustakaan asing disebut dengan istilah Alternative Dispute Solution (ADR) dalam bahasa Indonesia disebut dengan Alternatif Penyelesaian Sengketa (APS).

Alternatif Penyelesaian Sengketa / APS (termasuk arbitrase) dapat diberi batasan sebagai sekumpulan prosedur atau mekanisme yang berfungsi memberikan alternatif atau pilihan suatu tatacara penyelesaian sengketa melalui bentuk APS/Arbitrase agar memperoleh putusan akhir dan mengikat para pihak. Secara umum, tidak selalu melibatkan intervensi dan bantuan pihak ketiga yang indenpenden yang diminta membantu memudahkan penyelesaian sengketa tersebut. ${ }^{47}$

Adapun bentuk-bentuk Alternatif Penyelesaian Sengeketa (APS)/ Alternative Dispute Solution (ADS) adalah: ${ }^{48}$

a. Negosiasi adalah suatu penyelesaian sengketa dimana para pihak yang berbeda

47 Priyatna Abdurassyid, Arbitrase dan Alternatif Penyelesaian Sengketa, PT. Fikahati Aneska bekerjasama dengan Badan Arbitrase Nasional Indonesia (BANI), Jakarta, 2000, hal. 17

${ }^{48}$ Takdir Rahmadi, Op,Cit, 2015, hal. 287-288. Lihat juga Undang-Undang Nomor 30 Tahun 1999 tentang Arbitrase dan Penyelesaian sengketa. 
kepentingan mengadakan perundingan langsung, tanpa perantaraan atau bantuan pihak lain. Para pihak mengadakan tawar menawar tentang bentuk penyelesaian sengketa.

b. Konsiliasi adalah cara penyelesaian sengketa dimana para pihak meminta bantuan dari pihak lain yang netral guna membantu para pihak yang bersengketa dalam mencari bentuk penyelesaian sengketa.

c. Mediasi adalah cara penyelesaian sengketa dimana para pihak meminta bantuan dari pihak lain yang netral guna membantu para pihak yang bersengketa dalam mencari bentuk penyelesaian sengketa. Pihak ketiga itu tidak mempunyai kewenangan untuk mengambil suatu keputusan, tetapi hanya berwenang memberikan bantuan atau saran-saran yang berhubungan dengan soal-soal prosedural dan subtansial. Dengan demikian putusan akhir tetap di tangan para pihak yang bersengketa.

d. Arbitrase adalah acara penyelesaian sengketa dimana para pihak yang bersengketa menyerahkan pertikaian mereka kepada pihak lain yang netral guna mendapatkan keputusan yang menyelesaikan sengketa. Di dalam Undang-Undang Nomor 30 Tahun 1999 tentang Arbitrase dan Penyelesaian Sengketa dinyatakan bahwa Arbitrase adalah: cara penyelesaian suatu sengketa perdata di luar peradilan umum yang didasarkan pada perjanjian arbitrase yang dibuat tertulis oleh para pihak yang bersengketa.

e. Pencari fakta adalah cara penyelesaian sengketa dimana para pihak menyerahkan pertikaian mereka kepada pihak lain yang biasanya terdiri dari para pakar hukum untuk mencari fakta-fakta yang berkaitan dengan sengketa. Para pencari fakta mempunyai kewenangan untuk memberikan rekomendasi tentang cara penyelesaian sengketa yang bersangkutan.

Dalam Pasal 86 UUPPLH2009 ditentukan bahwa masyarakat dapat membentuk lembaga penyedia jasa penyelesaian sengketa lingkungan hidup yang bersifat bebas dan tidak berpihak. Pemerintah dapat memfasilitasi pembentukan lembaga penyedia jasa. Fungsi lembaga ini menurut PP 54 Tahun 2000 tentang Lembaga Penyedia Jasa Penyelesaian Sengketa Lingkungan Hidup adalah menyediakan pelayanan jasa penyelesaian sengketa lingkungan hidup dengan menggunakan arbiter atau mediator atau pihak ketiga lainnya. ${ }^{49}$

Kemunculan konsep penyelesaian sengketa altenatif ini (Alternative Dispute Solution/ADR) dilatarbelakangi oleh berbagai faktor diantaranya adalah:

${ }^{49}$ Baca lebih lanjut Pasal 86 UUPPLH-2009 dan PP 54 Tahun 2000 tentang Lembaga Penyedia Jasa Penyelesaian Sengketa Lingkungan Hidup. 
1. Ketidakpuasan terhadap sistem penyelesaian litigasi yang selalu bersifat formal (ordinary court)

2. Bahwasannya proses di pengadilan (litigasi) memakan waktu yang panjang (berlarutlarut)

3. Keuntungan menggunakan ADR/APS ini adalah bahwa rahasia para pihak terjaga karena bersifat tertutup.

4. Tujuan akhir dari Alternative Dispute Solution /ADS atau Alternatif Penyelesaian Sengketa / APS bukanlah menang kalah seperti di pengadilan tetapi tujuannya adalah memuaskan semua pihak (win-win solution)

5. Di bandingkan dengan ADS / APS biaya berpekara di pengadilan sangat sangat mahal karena proses persidangan yang terlalu lama tentu memakan biaya yang cukup besar belum lagi biaya untuk membayar pengacara.

6. Bahwasannya sistem penyelesaian sengketa di pengadilan tidak tuntas karena fokus solusinya mempermasalahkan masa lalu (the past) dan tidak memberikan penyelesaian masa datang (the future)

\section{Pilihan Penyelesaian Sengketa Lingkungan melaui Pengadilan}

Masalah lingkungan yang dapat menimbulkan sengketa yang dapat dibawa ke pengadilan adalah sengketa-sengketa yang dapat digolongkan kepada:

1. Sengketa yang merupakan wilayah hukum administratif

2. Sengketa yang merupakan wilayah hukum pidana

3. Sengketa yang bersifat perdata

4. Sengketa hukum internasional.

Pada tulisan ini penulis hanya fokus bagaimanakah prosedur penyelesaian sengketa perdata lingkungan melalui jalur pengadilan.

Penyelesaian sengketa lingkungan hidup melalui pengadilan bermula dari adanya gugatan dari pihak yang merasa dirugikan terhadap pihak lain yang dianggap penyebab kerugian itu. UUPPLH-2009 menyediakan dua bentuk tuntutan yang dapat diajukan oleh penggugat, yaitu meminta ganti kerugian dan meminta tergugat untuk melakukan tindakan tertentu. Agar tergugat dapat dijatuhi hukuman seperti yang dituntut oleh penggugat, maka harus ditentukan lebih dahulu, bahwa tergugat bertanggungjawab atas kerugian yang timbul. Di dalam ilmu hukum terdapat dua jenis tanggung gugat, yaitu tanggung gugat berdasarkan kesalahan (liability based on fault) dan tanggung gugat tidak berdasarkan kesalahan (liability without fault) atau yang disebut juga strict liability. ${ }^{50}$

\footnotetext{
${ }^{50}$ Takdir Rahmadi, Op.Cit, 2015, hal. 272.
} 
Tanggung gugat berdasarkan kesalahan ditemukan dalam rumusan Pasal 1365 KUH Pedata. Bahwa ketentuan Pasal 1365 KUH Perdata menganut tanggung gugat berdasarkan kesalahan dapat dilihat dari unsur-unsur rumusan pasal tersebut yaitu: ${ }^{51}$

a. Perbuatan tergugat harus bersifat melawan hukum

b. Pelaku harus bersalah

c. Ada kerugian

d. Adanya hubungan sebab akibat antara perbuatan dan kerugian

Penggugat yang mengajukan gugatan berdasarkan Pasal 1365 BW harus membuktikan terpenuhinya unsur-unsur tersebut agar gugatannya dapat dikabulkan oleh hakim. Salah satu unsur itu adalah bahwa tergugat bersalah. Dalam ilmu hukum kesalahan dapat dibedakan dalan dua kategori, yaitu kesengajaan dan kelalaian atau kealpaan. Jadi beradasarkan atas tanggung gugat berdasarkan kesalahan, adalah tugas penggugat untuk membuktikan adanya unsur kesengajaan atau kelalaian pada diri tergugat, sehingga telah menimbulkan kerugian pada diri penggugat. ${ }^{52}$

Selain tetap menganut tanggung gugat berdasarkan kesalahan, UUPPLH-2009 juga memberlakukan tanggung gugat tanpa kesalahan (strict liability)

${ }^{51}$ Lihat Pasal 1365 Kitab Undang-Undang Hukum Perdata (KUH Perdata)

${ }^{52}$ Takdir Rahmadi, Op.Cit, 2015, hal. 273 yaitu untuk kegiatan-kegiatan yang menggunakan bahan berbahaya dan beracun atau menghasilkan dan/atau mengelola limbah bahan berbahaya dan beracun dan/atau yang menimbulkan ancaman serius terhadap lingkungan hidup. Pada prinsipnya gugatan perdata pada sengketa lingkungan hidup yang paling sulit adalah bukan membuktikan ada tidaknya unsur kesalahan dari pelaku, tetapi membuktilkan adanya unsur hubungan sebab akibat antara perbuatan dengan kerugian penderita. Jika dikaitkan dengan kasus pencemaran lingkungan hidup, maka si penggugat harus dapat membuktikan bahwa kerugian yang dideritanya disebabkan oleh aktivitas industri atau pabrik menjadi tergugat. Pembuktian hal ini sangat sulit karena kompleksnya sifat-sifat zat kimia dan reaksinya satu sama lain maupun reaksinya dengan komponen abiotik dan biotik di dalam suatu ekosistem yang akhirnya berpengaruh pada kesehatan manusia. ${ }^{53}$

\section{KESIMPULAN}

Pada bagian penutup ini penulis mencoba menyimpulkan atas dua permasalahan yang penulis angkat pada tulisan ini yaitu apa yang dimaksud dengan sengketa lingkungan dimana fokusnya pada sudut pandang perdata lingkungan serta bagaimana mekanisme penyelesaian sengketa lingkungan dari sudut pandang perdata lingkungan baik itu litigasi maupun

${ }^{53}$ Ibid, hal. 273-274 
non litigasi. Bahwa hukum lingkungan keperdataan terutama mengatur perlindungan hukum bagi korban pencemaran dan/atau perusakan lingkungan akibat perbuatan pencemar yang menimbulkan kerugian bagi korban dan menyebabkan penderita berhak mengajukan gugatan ganti kerugian terhadap pencemar.

Dari pendapat diatas, jelaslah bahwa hukum lingkungan keperdataan secara substansial memuat ketentuan yang berkaitan dengan pemenuhan hak-hak keperdataan seseorang. Kelompok orang dan badan hukum perdata dalam kaitannya dengan lingkungan hidup yang baik dan sehat. Jika hakhak keperdataan ini dirugikan oleh salah satu pihak.

Sengketa lingkungan hidup (environmental disputes) sebenarnya tidak terbatas pada sengketa-sengketa yang timbul karena peristiwa pencemaran atau perusakan lingkungan hidup, tetapi juga meliputi sengketa-sengketa yang terjadi karena adanya rencana-rencana kebijakan pemerintah dalam bidang pemanfaatan dan peruntukan lahan, pemanfaatan hasil hutan, kegiatan penebangan, rencana pembangunan pembangkit tenaga listrik, rencana pembangunan waduk, rencana pembangunan saluran udara tegangan tinggi. Dengan demikian sengketa lingkungan mencakup konteks yang relatif luas.

Adapun penyelesaian sengketa lingkungan hidup keperdataan dapat dilakukan di dalam atau di luar pengadilan. Jika ingin menyelesaikan sengketa lingkungan keperdataan dengan melalui proses peradilan, bisa mengajukan gugatan ke Pengadilan. Gugatan bisa diajukan secara peribadi, kelompok dan gugatan dapat juga diajukan oleh Organisasi Lingkungan Hidup atau LSM yang peduli akan kelestarian lingkungan hidup. Gugatan perdata lingkungan diajukan bukan saja menyangkut kerugian (compensation), melainkan juga dalam gugatan untuk mempertahankan kepentingan lingkungan yang baik, serasi dan sehat bagi masyarakat banyak (public interest).

Mekanisme penyelesaian sengketa lingkungan keperdataan bisa juga melalui Alternatif Penyelesaian Sengketa (APS) yaitu penyelesaian sengketa diluar pengadilan dalam bentuk negosiasi, mediasi, konsiliasi, arbitase bahkan bisa juga diselesaikan melalui lembaga penyedia jasa yang dibentuk oleh masyarakat yang khusus menyelesaikan sengketa lingkungan hidup.

\section{DAFTAR PUSTAKA}

Abdurrasyid Priyatna, Arbitrase dan Alternatif Penyelesaian Sengketa Suatu Pengantar, PT. FIKAHATI ANESKA dan BANI, Jakarta 2002

Akib Muhammad, Hukum Lingkungan Perspektif Global dan Nasional, Rajawali Pers, Jakarta, 2014.

Rahmadi, Takdir, Hukum Lingkungan di Indonesia, Edisi Kedua, Rajwali Pers, Jakarta, 2015.

Siahaan, N.H.T, Hukum Lingkungan, Edisi Revisi, Pancuran Alam , Jakarta Timur, 2009. 
Sengketa Lingkungan Hidup Dalam Perspektif Hukum Perdata Lingkungan

Supramono, Gatot, Penyelesaian Sengketa lingkungan Hidup di Indonesia, Penerbit Renika, Jakarta, 2013.

Undang-Undang No 4 tahun 1982 tentang Ketentuan-Ketentuan Pokok Pengelolaan Lingkungan Hidup.

Undang-Undang Nomor 23 Tahun 1997 tentang Pengelolaan Lingkungan Hidup

Undang-Undang Nomor 4 Tahun 1999 tentang Kehutanan

Undang-Undang Nomor 30 Tahun 1999 tentang Arbitase dan Alternatif Penyelesaian Sengketa.

Undang-Undang Nomor 32 Tahun 2009 tentang Perlindungan dan Pengelolaan Lingkungan Hidup.

PP 54 Tahun 2000 tentang Lembaga Penyedia Jasa Penyelesaian Sengketa Lingkungan Hidup.

PERMA RI No 1 Tahun 2001 Tentang Acara Gugatan Perwakilan

Putusan MA RI tanggal 7 Juli 1971 No. 294/X/Sip/1971

Kitab Undang-Undang Hukum Perdata (KUH Perdata) 